\title{
Diagnosis cepat infeksi saluran kemih dengan menghitung jumlah leukosituria pada urinalisis metode flowcytometry sysmex ux-2000 dengan baku emas kultur urin di RSUP Sanglah Denpasar
}

\author{
Fernanda Savitri Mega Pratistha' ${ }^{1}$ I Wayan Sudhana ${ }^{2}$, I Wayan Losen Adnyana ${ }^{3}$
}

\footnotetext{
${ }^{1}$ Program Studi Pendidikan Dokter Fakultas Kedokteran Universitas Udayana

${ }^{2}$ Divisi Ginjal dan Hipertensi, Bagian IImu Penyakit Dalam, Fakultas Kedokteran Universitas Udayana-RSUP Sanglah Denpasar ${ }^{3}$ Divisi Hematologi Onkologi Medik, Bagian IImu Penyakit Dalam, Fakultas Kedokteran Universitas Udayana-RSUP Sanglah Denpasar
}

\begin{abstract}
Tujuan: Penelitian ini bertujuan untuk menentukan nilai sensitivitas, spesifisitas, dan akurasi pada Urinalisis Otomatis metode Flowcytometry menggunakan Sysmex UX-2000.

Metode: Penelitian ini merupakan penelitian uji diagnostik dengan menggunakan data rekam medis pasien yang didiagnosis secara klinis mengalami ISK di RSUP Sanglah pada tahun 2016 sampai dengan 2017. Subjek penelitian berjumlah 100 orang dengan rentang usia 2 tahun sampai dengan diatas 65 tahun. Analisis statistik menggunakan program komputer SPSS.23 dan kurva receiver operating characteristic (ROC) untuk mendapatkan cut-off point leukosituria paling optimal lalu dihitung sensitivitas, spesifisitas, nilai prediksi positif, nilai prediksi negatif dan akurasinya.

Hasil: Berdasarkan analisis kurva ROC didapatkan area under the curve (AUC) jumlah leukosituria berdasarkan metode flowcytometry sebesar 0,846 dan dengan menggunakan cut-off point $\geq 52,8 / \mathrm{mL}$, memberikan hasil sensitivitas $82,3 \%$ spesifisitas $76,3 \%$, nilai prediksi positif $85 \%$ nilai prediksi negatif $72,5 \%$ dan akurasi $80 \%$.

Simpulan: Alat Urinalisis Otomatis dengan metode Flowcytometry memiliki nilai sensitivitas, spesifisitas, dan akurasi yang tinggi sehingga dapat diterapkan untuk membantu diagnosis ISK.
\end{abstract}

Kata Kunci: Infeksi Saluran Kemih, urinalisis metode flowcytometry, Kultur urin

Aim: This study aimed to determine the sensitivity, specificity, and accuracy on the automatic urine analyzer by flowcytometry of Sysmex UX-2000.

Methods: This was a diagnostic test study. Data used in this study were patients diagnosed with UTI clinically in Sanglah Central Hospital from 2016 until 2017. Subject of the study were 100 people with aged 2 years till up to 65 years old. The statistical analysis computer program was SPSS.23 and receiver operating characteristic (ROC) curve was utilized to obtain the most optimal cut-off point for leukocytes count then calculated sensitivity, specificity, positive predictive value, negative predictive value and accuracy.

Results: Based on ROC curve analysis showed an area under the curve (AUC) for leukocytes count was 0.846 and cut-off point of $\geq 52.8 / \mathrm{mL}$ has a sensitivity of $82,3 \%$, specificity $76,3 \%$, positive predictive value $85 \%$, negative predictive value $72.5 \%$ and accuracy $80 \%$.

Conclusion: Automatic Urine Analyzer by Flowcytometry Method has high Sensitivity, Specificity, and Accuracy so that it can be applied to help diagnosed UTI.

Keyword: Urinary Tract Infection, flowcytometry urine analyzer, Urine Culture.
Tanggal diterima : 2 Agustus 2017 Tanggal Disetujui : 20 Agustus 20187 Tanggal Diterbitkan : 30 September 2017 
saluran kemih seperti adanya kista dan divertikel, serta defek neurologis yang menyebabkan retensi urin. Adanya benda asing pada saluran kemih, keabnormalitasan metabolik dan menurunnya status imunitas juga dapat memicu timbulnya ISK. ${ }^{2}$ Diagnosis ISK dapat ditegakkan apabila hasil anamnesis sesuai dengan gejala, pemeriksaan fisik menunjukkan adanya nyeri tekan suprapubik yang dipastikan dengan pemeriksaan urin mikroskopik yang menunjukkan peningkatan $>10^{3}$ bakteri per lapang pandang. ${ }^{3}$

ISK dapat disebabkan oleh beberapa jenis bakteri. Jenis bakteri penyebab ISK dapat diketahui dengan cara melakukan kultur pada urin yang dilakukan pada pasien dengan ISK berulang atau ISK dengan komplikasi. ${ }^{3}$

Diagnosis ISK selama ini didasarkan pada anamnesis dan pemeriksaan fisik yang mendukung adanya tanda dan gejala terjadinya ISK. Pemeriksaan penunjang dibutuhkan untuk menentukan penatalaksanaan yang sesuai dengan penyakit yang terdiagnosis. Pemeriksaan penunjang ISK selama ini menggunakan baku emas berupa kultur urin untuk melihat adanya patogen penyebab ISK dan jumlah kolonisasi bakteri yang digunakan sebagai salah satu syarat dari diagnosis ISK. ${ }^{4}$ Kultur urin memiliki kelemahan berupa mahal dan lama serta dapat memperoleh hasil negatif hingga 60-80\% sehingga dibutuhkan baku standar diagnostik baru yang dapat mengantikan kultur urin. ${ }^{4,5}$ Sebuah alat diagnostik baru yang bekerja secara otomatis sudah mulai banyak digunakan pada beberapa pusat kesehatan berupa metode flowcytometry yang dapat mendeteksi partikel dalam urin termasuk leukosit dan bakteri dalam waktu yang cepat dengan mewarnai partikel dalam urin menggunakan pewarna floresen, dalam studi dikatakan bahwa alat ini memiliki sensitivitas $89 \%$ dengan spesifisitas $79 \%{ }^{6}$

Pengobatan ISK berdasarkan pedoman praktik klinis dari fasilitas pelayanan kesehatan primer yang terbaru pada tahun 2014 dibagi menjadi 2 bagian utama, yaitu tata laksana nonfarmakologis yaitu dengan minum air putih minimal 2 liter/hari, dan menjaga kebersihan genitalia eksternal, sedangkan tata laksana dengan medikamentosa berupa pemberian tablet trimetropim-sulfametaksasol sebanyak 2 tablet untuk 2 kali minum selama 3 hari atau pemberian tablet ciprofloksasin 500 mg 2 kali sehari yang dikonsumsi selama 3 hari. Mengingat resistensi bakteri penyebab ISK yang dominan (E.Coli) pada kedua jenis obat diatas cukup tinggi, hal ini menjadi sebuah masalah yang harus diperhatikan untuk strategi penatalaksanaan kasus ISK. ISK yang tidak ditangani dengan baik akan menimbulkan komplikasi berupa ISK yang sering kambuh, gagal ginjal, dan sepsis. ${ }^{3}$

Diagnsosis tepat dari ISK dirasa sangat penting untuk diketahui agar dapat memberikan pasien pengobatan yang sesuai. Baku emas yang selama ini digunakan masih merupakan hal yang sulit dilakukan mengingat biaya yang tinggi dan waktu pemosresan yang lama. Oleh karena itu, penulis tertarik untuk membuat sebuah penelitian Uji Diagnostik mengenai nilai diagnostik dari urinalisis otomatis metode flowcytometry (Sysmex, UX-2000 corp., Japan) terhadap kultur urin sebagai baku standar untuk alat diagnosis penunjang ISK. Penelitian ini akan dilaksanakan dengan pengambilan data rekam medis pasien di bagian ilmu penyakit dalam RSUP Sanglah Denpasar, dimana rumah sakit tersebut bukan hanya menjadi rujukan utama pasien se-Bali akan tetapi menjadi rujukan utama se-Indonesia Timur. Penelitian ini penting dilakukan untuk mengetahui nilai diagnostik urinalisis otomatis dengan metode Flowcytometry sysmex ux-2000 sehingga kedepannya dapat memudahkan dan mempercepat diagnosis ISK, sehingga didapatkan kemajuan dalam penanganan ISK.

\section{Metode}

Jenis penelitian merupakan uji diagnostik untuk menganalisis sensitivitas, spesifisitas, nilai prediksi positif, nilai prediksi negatif, dan nilai akurasi dari pemeriksaan Urinalisis metode flowcytometry. Penelitian ini dilakukan di RSUP Sanglah pada bulan Juni-Oktober 2017. Subjek penelitian berasal dari data rekam medis pasien yang mengalami ISK dan diperiksa kultur urin serta flowcytometry urin. Subjek dicari melalui metode konsekutif hingga terpeuhi jumlah subjek yang diinginkan. Analisis data melalui kurva receiver operating characteristic (ROC) dan tabel $2 \times 2$ yang kemudian ditentukan nilai sensitivitas, spesifisitas, positive predictive value (PPV), negative predictive value dan akurasi dalam mendiagnosis ISK.

\section{Hasil}

Penelitian ini menggunakan data rekam medis pasien yang didiagnosis secara klinis menderita Infeksi Saluran Kemih (ISK) di RSUP Sanglah tahun 2016 sampai dengan 2017. Penelitian ini dilaksanakan pada bulan Juli sampai dengan Oktober 2017 dan didapatkan 100 jumlah subyek penelitian yang memenuhi kriteria inklusi. Karakteristik subjek dapat dilihat pada Tabel 1.

Berdasarkan Tabel 1 diatas dapat diketahui dari 100 subjek, rerata usia pada kasus ISK adalah 47,7 tahun dengan proporsi terbanyak pada rentang usia 25 sampai dengan 59 tahun, yaitu sebanyak 57 orang (57\%). Berdasarkan jenis kelamin dapat diketahui bahwa dari 100 subjek yang didiagnosis secara klinis mengalami ISK pada periode tahun 2016 sampai dengan 2017, kasus paling sering dialami oleh perempuan dengan jumlah 52 orang (52\%). Berdasarkan hasil kultur urin dapat diketahui dari 100 pasien yang didiagnosis secara klinis mengalami ISK terdapat 62 orang (62\%) dengan hasil kultur positif, dan 38 orang (38\%) hasilnya negatif. Jenis bakteri penyebab ISK berdasarkan kultur urin dapat dilihat pada Tabel 2. 
Berdasarkan Tabel 2 diatas diketahui bahwa dari 100 sampel kultur urin terdapat tiga jenis bakteri terbanyak sebagai penyebab ISK yaitu Eschericia coli sebanyak 44 (44\%), Klebsiela pneumonia sebanyak 9 (9\%), dan Acinetobacter baumanii sebanyak 6 (6\%). Nilai sensitivitas, spesifisitas, $P P V, N P V$, dan akurasi dapat dilihat pada Tabel 3.

Dengan menggunakan jumlah kuman $\geq 10^{5} \mathrm{CFU} /$ $\mathrm{mL}$ pada kultur urin diperoleh cut-off point terbaik jumlah leukosituria menggunakan metode flowcytometry sebesar 52,8 cell/mL dan memberikan hasil sensitivitas $82,3 \%$, spesifisitas $76,3 \%$, nilai prediksi positif $85 \%$, nilai prediksi negatif $72,5 \%$ dan akurasi $80 \%$.

Berdasarkan analisis kurva ROC didapatkan area under the curve (AUC) jumlah leukosituria berdasarkan metode flowcytometry Sysmex UX-2000 berdasarkan hasil kultur urin menggunakan jumlah kuman $\geq 10^{5} \mathrm{CFU} / \mathrm{mL}$ adalah sebesar $0,846(p<0,005)($ Gambar 1.$)$

Tabel 1. Karakteristik Subjek

\begin{tabular}{ccc}
\hline Karakteristik & $\begin{array}{c}\text { Frekuensi } \\
(\mathbf{n})\end{array}$ & $\begin{array}{c}\text { Persentase } \\
(\%)\end{array}$ \\
\hline Usia & & \\
Rerata \pm S.B & $47,7 \pm 19,2$ & $9 \%$ \\
Anak-anak $(0-14)$ & 9 & $5 \%$ \\
Remaja $(15-24)$ & 5 & $57 \%$ \\
Dewasa $(25-59)$ & 57 & $29 \%$ \\
Manula $(\geq 60)$ & 29 & \\
Jenis Kelamin & & $48 \%$ \\
Laki-laki & 48 & $52 \%$ \\
Perempuan & 52 & \\
Kultur urin & & $62 \%$ \\
Kultur positif & 62 & $38 \%$ \\
Kultur negatif & 38 & $100 \%$ \\
\hline$\quad$ Total & 100 & \\
\hline
\end{tabular}

\section{Pembahasan}

Berdasarkan hasil penelitian, pada Tabel 1 yang menjabarkan usia pasien ISK didapatkan hasil bahwa kasus ISK lebih sering terjadi pada sekelompok usia dengan rentang 25 sampai dengan 59 tahun yang termasuk dalam kategori dewasa dan $\geq 60$ tahun. Penelitian yang dilakukan sebelumnya menemukan bahwa kasus ISK paling banyak terjadi pada usia $\geq$ 60 tahun. Penelitian lain juga mendapatkan hasil yang hampir sama yaitu paling sering terjadi pada usia $\geq 45$ tahun. Kejadian ISK meningkat pada usia dewasa dan manula disebabkan oleh karena adanya aktivitas seksual, penyakit kronis, gangguan fungsional genitourinaria, dan penggunaan obat-obatan tertentu.

Hasil penelitian didapatkan hasil bahwa subjek pada jenis kelamin perempuan lebih banyak mengalami ISK dibandingkan laki-laki dengan jumlah subjek sebesar 52 (52\%) dari total subjek yang digunakan. Hasil ini sesuai dengan

Tabel 2. Bakteri penyebab ISK berdasarkan kultur urin

\begin{tabular}{lcc}
\hline Jenis Kuman & $\mathbf{n}$ & $\%$ \\
\hline Eschericia coli & 44 & $44 \%$ \\
Klebsiela pneumonia & 9 & $8 \%$ \\
Acinetobacter baumanii & 6 & $6 \%$ \\
Pseudomonas aeruginosa & 4 & $4 \%$ \\
Enterobacter cloacae & 3 & $3 \%$ \\
Enterococus taeccium & 3 & $3 \%$ \\
Serratia fonticola & 2 & $2 \%$ \\
Enterococcus faecalis & 1 & $1 \%$ \\
Morganela morganii & 1 & $1 \%$ \\
Providencia stuartii & 1 & $1 \%$ \\
Proteus mirabilis & 1 & $1 \%$ \\
Citobacter youngae & 1 & $1 \%$ \\
Stapilokokus epidermis & 1 & $1 \%$ \\
Tidak ada pertumbuhan & 23 & $23 \%$ \\
\hline Total & 100 & $100 \%$ \\
\hline
\end{tabular}

Tabel 3. Sensitivitas, spesifisitas, $P P V, N P V$, dan akurasi dari flowcytometry

\begin{tabular}{cccccccc}
\hline No & $\begin{array}{c}\text { Cut-off point leu- } \\
\text { kosituria (cell/mL) }\end{array}$ & $\begin{array}{c}\text { Sensitivitas } \\
\%\end{array}$ & $\begin{array}{c}\text { Spesifisitas } \\
\%\end{array}$ & $\begin{array}{c}P P V \\
\%\end{array}$ & $\begin{array}{c}N P V \\
\%\end{array}$ & $\begin{array}{c}\text { Akurasi } \\
\%\end{array}$ & AUC \\
\hline 1 & 40,5 & $85,5 \%$ & $71,1 \%$ & $82,3 \%$ & $75 \%$ & $80 \%$ & $84,6 \%$ \\
2 & 52,8 & $82,3 \%$ & $76,3 \%$ & $85 \%$ & $72,5 \%$ & $80 \%$ & $84,6 \%$ \\
3 & 59,4 & $80,6 \%$ & $76,3 \%$ & $84,7 \%$ & $70,7 \%$ & $79 \%$ & $84,6 \%$ \\
\hline
\end{tabular}

*PPV (positive predictive value), NPV (negative predictive value), AUC (area under the curve) 


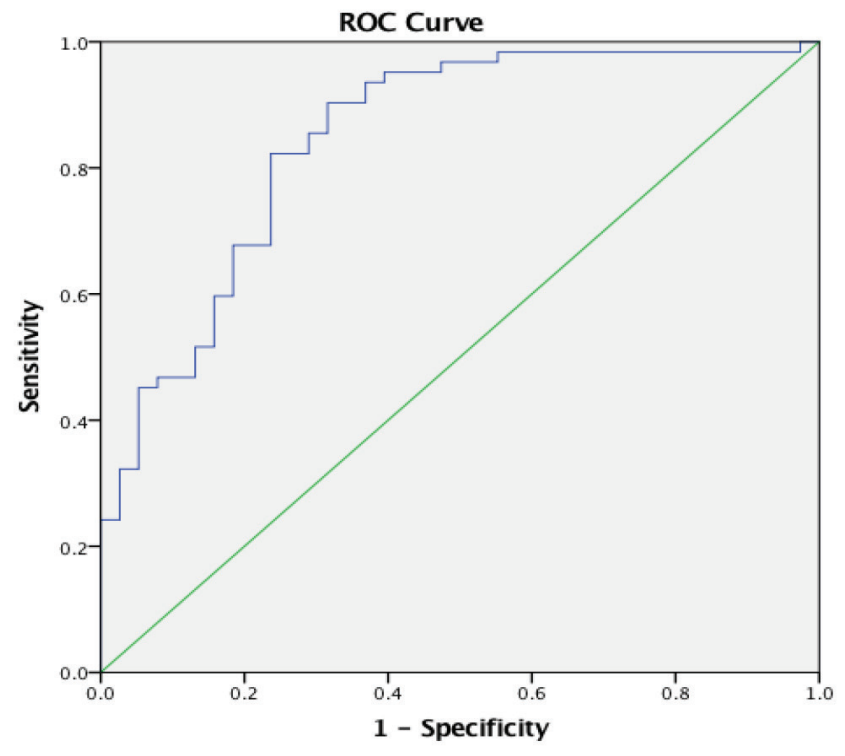

Gambar 1. Kurva ROC jumlah leukosituria berdasarkan metode flowcytometry dengan jumlah kuman $\geq 10^{5} \mathrm{CFU} / \mathrm{mL}$, $\mathrm{AUC}=0,846(p<0,005)$

penelitian lain, yaitu didapatkan angka kejadian ISK pada perempuan lebih sering daripada laki-laki dengan proporsi 63 orang $(65,6 \%)$. Penelitian lain yang dilakukan sebelumnya juga mendapatkan hal yang sama yaitu perempuan lebih sering daripada laki-laki sebanyak 58 orang $(56,86 \%)$. Hal ini disebabkan karena faktor anatomis dari alat genital perempuan yang memiliki uretra lebih pendek sehingga memudahkan untuk terjadinya ISK dibandingkan dengan laki-laki. ${ }^{8}$

Hasil penelitian menunjukkan bahwa dari 100 sampel urin yang dilakukan kultur urin terdapat 62 sampel urin yang menghasilkan pertumbuhan bakteri sebesar $\geq 10^{5}$ dan dinyatakan memiliki hasil positif. Pada pemeriksaan kultur urin terhadap 100 sampel urin didapatkan 13 jenis bakteri penyebab ISK pada subjek penelitian ini dengan Eschericia coli merupakan penyebab terbanyak dengan jumlah $44 \%$. Studi lain yang dilakukan mendapatkan hasil yang sama yaitu Eschericia coli sebagai penyebab terbanyak ISK dengan jumlah 18 (72\%) dari 25 sampel urin yang dilakukan kultur urin.

Dari penelitian uji diagnostik ini didapatkan hasil cutoff point terbaik jumlah leukosituria menggunakan metode flowcytometry dengan menggunakan jumlah kuman $\geq 10^{5}$ $\mathrm{CFU} / \mathrm{mL}$ pada kultur urin adalah $52,8 / \mathrm{mL}$, memberikan nilai sensitivitas $82,3 \%$, spesifisitas $76,3 \% \%$, nilai prediksi positif $85 \%$, nilai prediksi negatif $72,5 \%$, dan akurasi $80 \%$. Nilai sensitivitas $82,3 \%$ berarti kemampuan jumlah leukosituria dengan metode flowcytometry senilai $\geq 52,8 / \mathrm{mL}$ menyatakan seseorang benar mengalami ISK sebesar $82,3 \%$, sedangkan spesifisitas $76,3 \%$ berarti kemampuan jumlah leukosituria dengan metode flowcytometry senilai $<52,8 / \mathrm{mL}$ menyatakan seseorang benar sehat sebesar 76,3\%. Nilai prediksi positif $85 \%$ berarti kemungkinan seseorang dengan jumlah leukosituria $\geq 52,8 / \mathrm{mL}$ dinyatakan benar sakit sebesar $85 \%$ nilai prediksi negatif berarti kemungkinan seseorang dengan jumlah leukosituria $<52,8 / \mathrm{mL}$ dinyatakan benar sehat sebesar 72,5\%.

Hasil nilai cut-off point terbaik jumlah leukosituria menggunakan metode flowcytometry ini lebih rendah dibandingkan penelitian lain yang dilakukan dengan hasil jumlah leukosituria $\geq 300,7 / \mathrm{mL}$ dengan menggunakan jumlah kuman pada kultur urin positif $\geq 10^{5}$ dengan hasil sensitivitas $84,6 \%$, spesifisitas $75 \%$, nilai prediksi positif $95,5 \%$, dan nilai prediksi negatif $43,8 \%$. Bila dibandingkan dengan penelitian yang telah dilakukan, nilai spesifisitas dan nilai prediksi negatif dengan nilai cut-off point jumlah leukosituria menggunakan metode flowcytometry $\geq 52,8 / \mathrm{mL}$ pada penelitian ini lebih tinggi yaitu $76,3 \%$ dan $72,5 \%$

Pada penelitian sebelumnya yang dilakukan oleh Giesen $\mathrm{dkk}^{6}$ pada tahun 2016, pemeriksaan leukosituria metode flowcytometry memiliki sensitivitas $89 \%$, spesifisitas $79 \%$, nilai prediksi positif $38 \%$, dan nilai prediksi negatif 98\% dengan menggunakan cut-off point jumlah leukosituria $\geq$ $31,8 / \mathrm{mL}$ dan jumlah kultur urin positif $\geq 10^{5} \mathrm{CFU} / \mathrm{ml}$ urin. Penelitian kali ini memiliki nilai sensitivitas dan spesifisitas yang lebih tinggi

Agpaoa dkk juga melakukan penelitian serupa pada tahun 2015 di Filipina namun dengan jumlah kultur urin positif yang berbeda yaitu $\geq 10^{3}$ memiliki cut-off point terbaik jumlah leukosituria menggunakan metode flowcytometry senilai $\geq 27 / \mathrm{mL}$ mendapatkan hasil sensitivitas $84,6 \%$, spesifisitas $65,4 \%$, nilai prediksi positif $71 \%$, dan nilai prediksi negatif $81 \%$. Jika dibandingkan, penelitian ini memiliki nilai sensitivitas dan nilai prediksi negatif yang lebih rendah dengan nilai spesifisitas dan nilai prediksi positif yang lebih tinggi.

Banyaknya variasi cut-off point jumlah leukosituria dalam mendiagnosis ISK dapat disebabkan karena beberapa hal. Pertama, terdapat perbedaan karakteristik sampel yang masuk dalam kriteria inklusi, seperti adanya variasi dalam usia sampel penelitian, dimana pada usia tua dapat terjadi penurunan dari sistem pertahanan tubuh sehingga akan berpengaruh terhadap jumlah leukosit yang dihasilkan. Kedua, perbedaan populasi dari setiap penelitian, karena faktor lingkungan juga akan mempengaruhi prevalensi terjadinya ISK disetiap wilayah sehingga akan berpengaruh juga terhadap jumlah sampel yang digunakan, dan ketiga akibat perbedaan definisi dalam jumlah biakan urin sebagai positif ISK yang digunakan dalam penelitian., ${ }^{910}$

Diagnosis ISK membutuhkan waktu yang cepat dan penanganan yang adekuat sehingga ISK dapat terkontrol dengan baik. Keterlambatan dalam mendiagnosis ISK akan memperlambat penanganan ISK secara efektif sehingga 
kualitas kesehatan pasien akan menurun diikuti dengan peningkatan resiko terjadinya komplikasi. Pada penelitian ini didapatkan nilai AUC sebesar 84,6\% sehingga pemeriksaan urinalisis metode flowcytometry dengan nilai cut-off point jumlah leukosituria $\geq 52,8 / \mathrm{mL}$ memiliki akurasi yang baik secara statistik dan dapat diterapkan.

Penelitian ini memiliki keterbatasan yaitu tidak memperdulikan pola pemberian antibiotika pada pasien yang menjadi sampel dalam penelitian, sehingga dapat meningkatkan terjadinya negatif palsu. Sampel pada penelitian ini juga menggunakan data rekam medis pasien, sehingga tidak dapat dikontrol dengan baik prosedur pengambilan sampel urin untuk pemeriksaan urinalisis dan kultur urin.

\section{SIMPULAN}

Hasil penelitian dapat disimpulkan bahwa nilai sensitivitas, spesifisitas, dan akurasi urinalisis otomatis dengan metode flowcytometry adalah tinggi sehingga dapat diterapkan dalam membantu diagnosis ISK.

\section{DAFTAR PUSTAKA}

1. Pradani S. Pola kuman dan resistensi bakteri terhadap antibiotik pada penderita infeksi saluran kemih (ISK) di instalasi rawat inap rumah sakit PKU Muhammadiyah Surakarta periode februari-maret tahun 2016. Publikasi universitas muhhamadiyah. 2016.

2. Rane A, Dasgupta R. Urinary Tract Infection. Springer. 2013;62(6):287-91.

3. Smelov V, Naber K, Johansen T. Improved classification of urinary tract infection: future consideration. European Association of Urology. 2016;2(3):44-8.
4. Agpoa V, Mendoza J, Fernandez A. Predict urinary tract infection and to estimate causative bacterial class in a Philipine Subspeciality Hospital. J Nephrol Ther. 2015;6(1):64-9.

5. Broeren M, Bahcecu S, Vader H. Screening for urinary tract infection with Sysmex-UX2000 Urine Flow Cytometer. Journal of Clinical Microbiology. 2010;12(6):128-34.

6. Giesen C, Greeno A, Thompson K. Performance of flow cytometry to screen urine for bacteria and white blood cell prior to urine culture. Clinical Biochemistry. 2013;4(2):68-72.

7. Foxman B. Epidemiology of Urinary Tract Infection: Incidence, morbidity, and economic cost. Am J Med. 2002;5(3):68-72.

8. Wsarachkitti B, Kherjonnit V, Pratumvinit B. Performance Evaluation and comparison of the fully automated urinalysis analyzers UX 2000 and Cobas 6500. Laboratory Medicine. 2016;4(3):81-4.

9. Krongvorakul J, Phundhusuwanakul S, Santanirand P, et al. A flowcytometric urine analyzer for bacteria and white blood cell count plus urine dipstick test for rapid screening of bacterial urinary tract infection. Asian Biomedicine. 2012;9(1):110-4.

10. Filia Clementy. Uji Diagnostik Leukosituria dan Bakteriuria Mikroskopis Langsung Sampel Urin Untuk Mendeteksi Infeksi Saluran Kemih. Publikasi Universitas Diponegoro. 2013.

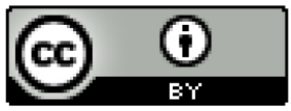

This work is licensed under a Creative Commons Attribution 4.0 International License. 